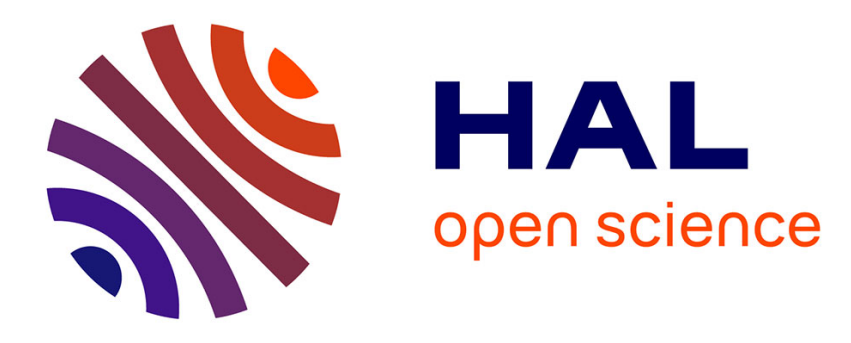

\title{
The Veiled Muslim, the Anorexic and the Transsexual Randi Gressgård
}

\section{To cite this version:}

Randi Gressgård. The Veiled Muslim, the Anorexic and the Transsexual. European Journal of Women's Studies, 2006, 13 (4), pp.325-341. 10.1177/1350506806068651 . hal-00571282

\section{HAL Id: hal-00571282 \\ https://hal.science/hal-00571282}

Submitted on 1 Mar 2011

HAL is a multi-disciplinary open access archive for the deposit and dissemination of scientific research documents, whether they are published or not. The documents may come from teaching and research institutions in France or abroad, or from public or private research centers.
L'archive ouverte pluridisciplinaire HAL, est destinée au dépôt et à la diffusion de documents scientifiques de niveau recherche, publiés ou non, émanant des établissements d'enseignement et de recherche français ou étrangers, des laboratoires publics ou privés. 


\title{
The Veiled Muslim, the Anorexic and the Transsexual
}

\section{What Do They Have in Common?}

\author{
Randi Gressgård \\ UNIVERSITY OF STAVANGER
}

\begin{abstract}
The Muslim woman wearing the veil, the female anorexic and the from-male-to-female transsexual constitute three different figures that, despite their striking differences, have a common symbolic ground. By focusing on the similarity between the veiled woman and the other two figures, the article sheds a different light on the debate about the Muslim veil in western societies. It is argued that the western notion of woman is based on a structural ambivalence of transcendence and immanence. On the one hand, woman is expected to be liberated, in control and active in public life and in all ways just as free as the man, on the other she represents a deficiency compared to the man; it is expected of her that she takes up a complementary, subordinate position in relation to the man. The subordinate position, however, is seldom pronounced. Officially, the gender hierarchy is not a part of egalitarian societies, that is, the modern configuration that formally rejects a hierarchical worldview. Is this the reason why the three figures are regarded as pathological? Does their way of demonstrating extraordinary transcendence combined with extraordinary immanence make them monstrous?
\end{abstract}

KEY WORDS body-spirit dualism $\bullet$ gender construction $\bullet$ hierarchy $\bullet$ modern ambivalence the monstrous symbolic structures

The Muslim woman wearing the veil, the female anorexic and the frommale-to-female transsexual constitute three different figures that apparently do not have much in common. However, beneath the surface, on the structural level, a striking similarity is concealed. I approach the structural homology by asking what is special about these three figures. The purpose is to shed a different light on the debate about the Muslim veil.

Ever since France suggested a statutory prohibition against religious

European Journal of Women's Studies Copyright (C) 2006 SAGE Publications (London, Thousand Oaks and New Delhi), 1350-5068 Vol. 13(4): 325-341; http:/ / ejw.sagepub.com DOI: 10.1177/1350506806068651 
symbols in schools, the debate about the Muslim veil has gained momentum in western countries. ${ }^{1}$ What is it about this garment that gives rise to such ferocious debate and makes democratic states enact statutory prohibitions against it?

\section{THE TRADITIONAL SUBORDINATION OF WOMEN}

The veil is by many associated with a traditional subordination of women. Several Muslim women, however, and especially those having grown up in western societies, are of the opinion that the veil liberates them from the sexualized gaze of men (Jacobsen, 2002; Roald, 2001). The argument is that the veil conceals the gender and sexual dimensions, and that they therefore gain respect as human beings. In this way, in stark contrast to the arguments of its opponents, the idea of human equality or equal dignity is attached to the veil.

Regardless of position in the debate, the arguments seem to presuppose a common symbolic ground: the idea of a division between human universality and human specificity. On the one hand, it is a matter of an abstract, universal human being, without any kinds of social particularities; on the other, it is a matter of concrete human beings, with particular qualities and attributes, formed by the society and culture of which they are a part. This structural ambivalence regarding the view on humankind can be found within different historical epochs within both western and eastern ways of thinking.

The mere idea of human abstractness and universality constitutes a typically non-modern figure of thought, attached to the notion of a hierarchical order. In accordance with Louis Dumont (1970: 239ff.), we may present the hierarchy as follows: First God creates Adam, the undifferentiated man, the prototype of 'mankind'. Thereupon he creates Eve from Adam's rib as the second sex. Thus Adam and Eve appear as prototypes of the two sexes. However, due to this operation, Adam has changed identity; from being undifferentiated, universally human, he has become a distinct human being - a male. On the other hand, a being has appeared - woman - who is both a member of the human species and different from the main representative of this species. Hence, on a first level, man and woman are identical, whereas on a second level, woman is the contrary of man and takes up a second, subordinate position.

The subject is universal in the sense of being identical to itself and anybody else; it is an eternal, undifferentiated, indeterminate, indistinct absolute - in accordance with a metaphysical ideal of purity or sacredness. The order of society and nature, on the other hand, is earthly, differentiated and distinct. As soon as Adam and Eve eat from the tree of life, the world of distinctions is an irrevocable fact. This conception of 
the fall of man from divine grace is an important mythical structure, informing not only religious narratives, but also western subjectivity in general and most of the political ideologies (grand narratives) of western culture.

According to the occidental thought traditions, influenced by the philosophy of classical antiquity and Christianity, the notion of the universal human being is inextricably linked to the notion of the human spirit, as it is by virtue of being spiritual, distinct from physical, bodily existence, that human beings may be imagined as members of the human species. It is, in other words, because of their spiritual capacity that human beings are distinguished from the rest of nature. This means that the category 'human being', based on the universal identity of the human subject, is considered within the framework of dualism, e.g. the distinction between matter and spirit, body and soul, distinctions typical of religion and philosophy in western cultures (Dumont, 1970: 263). A chain of subordination goes from God to the universal, immortal human spirit and onward from the spirit to the mortal body. And God, through the spirit, is - as the creation story indicates - linked to the gender of the subject (Irigaray, 2004: 178), associated more with the man than with the woman. Woman does not have the same privileged divine filiation as man, since she is thought of as more hampered by, and subordinated to, limitations associated with mortal, earthly life and nature in particular.

When universality constitutes the utopian horizon, any specificity will necessarily appear as a lack to be overcome, insofar as any particular qualities reveal the gap between the universal, undifferentiated subject and the autonomous, differentiated subject, or - more specifically between the particular cultural identity and a universal civic identity (Lyotard, 1992: 45). Gender, in particular, is seen as the subject's failure to achieve the full identity of (civilized) man (Salecl, cited in Donald, 1996: 186; see also Irigaray, 2004), as woman is seen as subjected to the immanent, the physical, immediately discernible aspects of being a human animal (Clack, 2002: 7), which comprise those of the body, the natural, the bestial, the raw, the wild, etc. (see Butler, 1990; Grosz, 1994; Lloyd, 1984; Ortner, 1996).

Seen in this way, the distinction between spiritual universality and bodily distinctness constitutes an essential ambiguity or duality in the subject, raising the question of how the human subject can be universal (identical to itself and all others) and specific/autonomous (unique or different from all others) at the same time. As indicated earlier, modern ideologies seem to deal with the gap between universality and specificity/autonomy by incorporating the universal subject - the idea of the abstract man - into the autonomous male bourgeois subject (e.g. Braidotti, 1991; Mosse, 1985). ${ }^{2}$ In his capacity of transcending the basic physical facts of human existence, the autonomous, bourgeois man becomes a whole, 
universal human being, not via a religious, ascetic way of life, but via culture and intellectual life - in a civilizing process. ${ }^{3}$

The body, being subjugated to the spirit, acquires a symbolic meaning through mirroring the spirit. This scheme may translate into the following motto: 'a sound mind in a sound body' (Juvenal's Satires 10.356), whereas an impure body - a body showing, for instance, traces of improper behaviour - is often considered to bear witness to a bad mind, or a mind that (temporarily) has lost control over the body (e.g. Norman, 1991). The hierarchy has become reversed; the body has taken command of the mind.

Against this background, we may - in addition to modern subjectivity and ideologies - understand religiously motivated traditions of covering up the female body as well as a number of other practices, such as fasting and asceticism, related to the body. Often food is associated with desire, and hence fasting becomes an aspect of asceticism. According to Annemarie Schimmel (1997: 73), religions characterized by an ascetic strain operate with more or less negative images of women, because it is they who symbolize lust and desire. ${ }^{4}$ It is a general notion - be it secular or religious - that women are more chaotic and blurred in comparison to men, and that they need strict boundaries and male control (Økland, 2002: 144).

\section{THE HIERARCHICAL EGALITARIAN ORDER}

As pointed out, the symbolic hierarchical structure is not reserved for other epochs and other cultures; it is also operative - although indirectly - within contemporary western, egalitarian societies, that is, within the modern configuration that formally rejects a hierarchical structure (Dumont, 1996). Hierarchy is embedded in the very heart of the modern, egalitarian order, insofar as the idea that all human beings are equal is based on the image of the universal subject, the abstract nakedness of being nothing but human (Agamben, 1998; Arendt, 1973), in the same way that Christianity, relating to the notion of the universal human spirit, above particular bodies, is based on the image of an almighty God hovering above particular human beings. In that sense, human equality following from the conception of all humans as identical when abstracted from the matter/body - presupposes hierarchy, with man being in cahoots with the universal human spirit against woman and the body. So, as long as equality bears on the spirit, in hierarchical opposition to the body, equality bears on a hierarchical, gendered configuration.

This scheme inevitably manifests itself in a structural ambivalence of the construction of woman. Simone de Beauvoir (1952), confirming this symbolic structure, describes the ambivalence as a contradiction between being human and being feminine. On the one hand, the woman is 
expected to be transcendent (human) on par with the man. This means that she is expected to be modern, liberated, in control, active in public life, and in all ways just as free as the man: a free subjectivity defining its individual projects. On the other hand, the woman represents a deficiency compared to the man, which associates her to immanence. As an Other it is expected of her that she is the object for the male subject: that she is sexually available, that she supports the existing state of affairs connected to family, kin and private relations; in short, that she possesses a generic function and takes up a complementary, subordinate position in relation to the man.

The subordinate position of women, however, is hardly ever pronounced, and when it is pointed out, it is often justified by reference to personal solutions or pure love, and it is represented as a result of free individual choice (Haavind, 1982). One example of women's structural ambivalence is found in Lizett U. Skottestad's (2003) study of women who have undergone plastic surgery to enlarge their breasts. The study shows that the women who have gone through cosmetic surgery of this kind account for their choice by referring to the wish for a visible female facade that does not decay. At the same time, they desire respect and dignity as human beings, something that conspicuously big implants exclude (because big implants make the gender stand out). All the women emphasize that the choice was entirely their own without pressure from husbands or fiancés.

Similar reflections are found among women of an immigrant background in western countries. Several studies show that these women, often expressing it as 'maintaining the best of two cultures', wish to achieve balance between liberation and subordination. A study by Annick Prieur (2002: 161ff.) shows that for young immigrant women in Norway their host country is to be preferred with respect to the public sphere, and the country of origin as to the private sphere. They appreciate individual freedom and egalitarian gender relations together with an appreciation of traditional family life, associated with the authority of their parents and other elders. (The consideration towards the family implies that the choice of spouses and the sexual morals of women cannot be a matter of individual and free personal choice.)

Both examples can be seen as a matter of ambivalence between transcendence and immanence, where transcendence is understood in terms of liberation, freedom, equality and being in control, while immanence means subordination, submission and constraint.

The point in question is what happens when freedom and control are not balanced by submission - when the ambivalence between transcendence and immanence is striking? What happens when some women use their freedom to choose submission instead, that is, when someone freely chooses lack of freedom? A first answer is that the choices are not 
accepted by the surrounding world. Questions are raised as to the validity of the freedom of choice, and the independence of the actors is disputed. Often it is assumed that they act under the influence of 'false consciousness', not knowing their own good, as it were (Gressgård and Jacobsen, 2003). ${ }^{5}$

A more substantial answer could be that the surrounding world reacts because the women's ambivalence appears threatening to the system of order when it becomes too visible. The ultimate ambivalence, consisting of complete freedom and control combined with complete submission, contributes to the demonstration of a gendered hierarchical structure of supremacy and subordination, and that creates unrest within a cultural logic founded on a rejection of a hierarchical worldview. Here we are on the track to the similarity between the Muslim woman wearing the veil, the female anorexic and the from-male-to-female transsexual.

\section{THE VEILED WOMAN}

The idea of the Muslim veil as suppressive of women is well established in western societies. According to Leila Ahmed (1992: 152), western opposition to veiled women may be traced back to colonial times. The discourse on Islam during colonial times indicated that the religion as such was suppressing women, and that the veil, along with the segregation of the sexes, contributed to a reinforcement of suppression. The veil was established as the strongest sign of the inferiority of Muslim countries. It symbolized both suppression of women and the backwardness of Muslim countries, in contrast to the civilized West. (This was the case in the colonial period despite the fact that the western countries, England among them, were deeply patriarchal and suppressive of women, and that Queen Victoria, on many occasions, wore a veil herself.)

Needless to say, this opposition between a liberating West and a suppressive East structures the recent debates about the veil. ${ }^{6}$ (The opposition is operative despite the lack of a basis for claiming that the veil entails suppression, and that, on the other hand, western societies are just with respect to gender. The main object of the opposition seems to be the upholding of an egalitarian self-image.) However, what happens when Muslim women who are living in western democratic societies use feminist arguments, emphasize that wearing the veil is liberating, and insist on their freedom to choose? Given the well-established notion that the veil is suppressive, Muslim women's insistence that the veil is liberating, seems to create major confusion among the majority population. In order to understand the malaise that the veil arouses, we have to take as a starting point the western cultural tradition of thought as described earlier. 
Here it appears that veiled women take the ambivalence of modern women to its utmost limits. In consonance with the western cultural ideal of transcendence of immanence towards the abstract human being and universal equality among humans, Muslim women use arguments of freedom, control and liberation to explain and legitimize the concealment of those parts of the body that are assumed to arouse the lust of men. As they see it, human equality and dignity is accentuated by the liberation from the sexual gaze of men (e.g. Roald, 2001: $288 \mathrm{ff}.){ }^{7}$

Seen from a western cultural perspective, however, what happens in these cases is that transcendence towards a universal human being strikes back with full force. The reason is that during the process of desexualizing or disembodying themselves, the women - from a western point of view - accentuate those bodily attributes supposed to be hidden. As has been pointed out, in western societies the veil is considered an almost unambiguous symbol of women's subordination. At any rate, the veil is incompatible with the abstract, universal human being. So regardless of what the veil-wearing woman might herself think, she does not appear as transcendent, with the universal human subject having been incorporated into her specificity or autonomy. ${ }^{8}$ Her gender attributes make transcendence and immanence go hand in hand; control and freedom are accompanied by submission. It must also be added that her cultural difference strengthens the distance to the universal human being, as one can hardly get further away from the modern bourgeois ideal of man (see Ahmed, 1992). Thus the deficiencies of the Muslim woman, when compared to the idea of human universality, become overly manifest. It is here that the malaise arises, because suddenly the veiled Muslim becomes a parody of the western woman. The decisive point is that the Muslim woman does not achieve a sufficient balance between liberation and submission the way most western women do, in order to keep the hierarchical structure adequately at bay. Instead, she lives it out completely, and lays bare the symbolic framework of the modern construction of women.

\section{THE FASTING MEDIAEVAL WOMAN AND THE MODERN ANOREXIC}

In her book Den guddommelige anoreksi (Divine Anorexia), Monica Wegling (2002) compares modern female anorexics with fasting female Christian mystics of the Middle Ages. Her focus is on the structural homology between the fasting projects of the two epochs, where she argues that modern anorexia constitutes a variant of Christian asceticism of premodern times. ${ }^{9}$ As structural continuity is also my concern, I primarily relate to her text.

Christian women of the Middle Ages fasted in order to get closer to 
God; it was a matter of becoming one with the Passion of Christ. According to Caroline W. Bynum (1987: 179), the female body was an image for a God who died to give birth to the world and bled to feed all souls. Motherliness was used as a characterization of the care and love that the soul received from God, and Jesus was looked upon as a life-giving mother, which explains why the bleeding wounds of Christ were associated with food; why Christ was perceived as a mother figure due to bleeding, feeding and nursing. More generally, it explains why it was possible to associate the wounds of Christ with the woman's body and woman with the Eucharist. The Eucharist served as a reminder of the suffering body of Christ, and gradually hunger became a preparation for the Lord's Supper, insofar as it expressed a hunger or longing for God, but also for the Passion of Christ. From a perspective such as this, food becomes more than a symbol, as food really turns into God. To eat God was the same as becoming the suffering body oneself; it was imitatio Christi (Wegling, 2002: 26). Uli Linke (1999: 137) claims that to eat God was becoming what the female symbolized: flesh, blood, nurture, suffering and regeneration.

For some female mystics, abstinence and the Eucharist constituted the essence of religious practice. Those who fasted gained honour and admiration by taking upon themselves the sins of humankind and doing penance. Also, they were considered particularly strong in the faith (Wegling, 2002: 22). Femininity, then, was both a means and an end, in that the worshipping women both chose as their starting point and became what woman symbolized, above all suffering. The divine was, in a sense, incorporated into the female body. At the same time, however, the fast constituted a suppression of the female body and its functions. Women who through fasting employed their female (bodily) qualities in order to serve God were said to bleed in a different way and to eject other kinds of bodily fluids. According to Linke (1999: 145), as part of their union with God, their behaviours were directed towards shutting off menstruation, excretion and other ordinary physical functions. Due to the fact that the body tied the spirit to the earth, and because eating strengthened this human connection to the earth, abstinence from food was regarded as the liberation of the spirit from the things of this world (Wegling, 2002: 52). In this sense, we may see it as a transcendence of immanence. However, because it happened to be femininity that was taken into the service of transcendence, and because the main goal was to affirm the Passion of Christ through an emphasis on his human/feminine sides (flesh, blood, nurture, suffering and regeneration), those who fasted fell back into immanence. For the mediaeval women, therefore, transcendence goes hand in hand with immanence, and both are taken to their utmost consequence.

Wegling (2002: 176) finds the connection to female anorexics of today in the ascetic ideal of declining temptations, and in its connection to strength 
and control. She emphasizes that modern anorexia is not only a matter of the body, but also - as in the Middle Ages - a matter of purification, purity, conscience and control. Both the modern and the non-modern fasters have brought moderation out of proportion by wanting to raise themselves above the limitations imposed by the perishable body. At the same time, she points out, they are dependent on that very same body to succeed (Wegling, 2002: 56).

The modern anorexic may triumph at the expense of her surroundings' addiction to pleasure as long as she does not show any signs of weakness, that is, as long as she appears controlled and of strong character. But at the very moment strength disappears, she will - seen from her surroundings - move from being the incarnation of control to losing it. From being completely transcendent she has collapsed into immanence.

The modern anorexic's lack of status is explained by the fact that we live in a society where enchantment is lost and only logically convincing arguments are considered viable (Wegling, 2002: 177). Accordingly, the anorexic is neither understood nor tolerated. (This in contrast to hunger strikers, who have a worthy cause and rationale of what they do.) Anorexia-death is without meaning, because we have forgotten its origins (Wegling, 2002: 182).

As already shown, the mediaeval ascetic emphasized the earthly character of the body as a means to reach God. The body constituted a physical obstacle that had to be transcended in order to reach the spiritual world, but thus it also provided her with the necessary help to get where she wanted (Wegling, 2002: 184). Because the goals of the mediaeval woman lay beyond this world, she could die without this representing any contrast to control and transcendence. In contrast, the modern anorexic has lost in her attempt of transcendence long before death occurs. She is not applauded on her way to death, and the reason is that death - and the way to get there - is associated with loss of control and freedom.

In modern society, eternity is usually not assumed to be achieved through dying, but by living in certain ways. This is related to the fact that the undifferentiated, eternal dimension - the universal subject - is incorporated into the autonomous, bourgeois man - a specific ideal of manliness. As demonstrated earlier, transcendence is a matter of distancing oneself from what may be deficient in relation to this ideal, everything and everybody that mark gaps on the way to perfection. Among these are found the uncontrolled anorexic woman.

Jorun Solheim's (1998) analysis of female anorexia draws in the same direction, although with a different focus (her focus is on the anorexic's relationship to her parents). Solheim claims that the anorexic's fanatical concern with purity, and the ruthless pursuit of perfection, points towards the anorexic girl's exaggerated identification with the image of the father. She wants to be perfect and pure, as opposed to deficient and impure, 
along the lines of the ideal male condition. In this, Solheim sees an obvious similarity to the women of the Middle Ages who fasted in order to get closer to eternity or divinity, in contrast to bodily femininity (Solheim, 1998: 114ff.). Within the emotional climate of the anorexic, femininity is a burden; it is heavy and earthly, while she wants to be free. Solheim states that the anorexic body symbolizes freedom from the burden of the bodily-determined fate of femininity (Solheim, 1998: 115).

Solheim (1998: 116) also emphasizes another important aspect of modern anorexia: what may represent liberation to women, may, from a male point of view, represent a neutralization and undermining of the strength of women (symbolized by the mighty mother figure). Perceived this way, modern, female anorexia can be understood as an escape from a form of sexual dualism that incarnates femininity as body, flesh, food and mother (cf. the mediaeval image of woman), but which, in its denial of this image of woman, reproduces the same dualism along the opposite pole. It raises masculinity to become the ideal. Solheim concludes that in the last instance, on its most general and fundamental level, the anorexic message may be read as follows: you shall never be free and perfect, you may never be yourself in a woman's body. The more the woman tries to transcend, it seems, the more her attempts are bound to strike back into immanence. As the standard for evaluation is defined by a certain male ideal, the result is given: as 'different', one is judged in advance. Any attempt to live up to the ideal will end up in an accentuation of deficiency.

The fact that transcendence towards universality is incorporated into a specific entity that constitutes a particular ideal and defines a particular standard to live up to, makes it hard to catch sight of the underlying metaphysical notion of totality and hierarchy. Apparently society is based on egalitarianism, but nevertheless, underneath lies hidden a non-modern, hierarchical symbolic structure. We may conclude that the anorexic takes the consequences of living as a woman in such a society. The apprehension of this, however, implies that we recognize the non-modern configuration on which the hierarchical structure is based, and that is evidently more than society can bear.

\section{THE TRANSSEXUAL}

Concerning liberation, the transsexual who changes from being a man into becoming a woman goes in the opposite direction to the two other figures. The project of the transsexual is not liberating in the sense of transcending immanence, but in the sense of transgression - from one sex to the other. A common trait is that liberation is a matter of becoming complete as opposed to being divided between body and spirit. Only, in this case it is a matter of becoming one sex or one gender, and not of 
becoming a human being liberated from bodily attributes. However, as is the case with the Muslim and the anorexic, here also the hierarchical division between body and spirit imposes a fundamental symbolic structure. In the case of transsexuality the division becomes particularly visible, since the starting point is that the body is to such a small extent in harmony with the spirit, that it is necessary to carry out dramatic surgical intervention. Thus the transsexual not only demonstrates the hierarchical division between body and spirit, but also that the spirit is gendered, which means that a female spirit demands a female body, and correspondingly, a male spirit demands a male body.

I refer to Tordis Borchgrevink's (1987) book Kjærlighetens Diktatur. Kjønn, arbeidsdeling og modernitet (The Dictatorship of Love: Sex, Division of Labour and Modernity) in order to illuminate what transsexuality can tell us about the modern configuration, or more precisely, about the relationship between liberation and submission.

Borchgrevink emphasizes that transsexuality is a matter of creating oneself as complete, to become self-identical, which implies that the body is adapted to the spirit. The body is a means for giving the 'head' what the 'head' legitimately demands, she maintains (Borchgrevink, 1987: 57). In this sense - of voluntarily altering one's body - transsexuality comprises a central aspect of freedom of choice, control, responsibility and intention. Borchgrevink (1987: 97) finds that transsexuals choose more radically than most people do.

But what do they choose? According to Borchgrevink, the transsexual 'person' ought to be so restlessly engaged in the definition of the sex he or she wishes to belong to, that the surroundings do not even notice that a change has occurred (Borchgrevink, 1987: 60). For this reason the transsexual is subjected to a psychiatric examination, before the operation, during which it is decided whether he or she is able to act convincingly as the 'new' gender, or whether he or she runs the risk of being disclosed.

Borchgrevink (1987: 62) argues that doctors define their success by the extent to which the transsexual is able to adapt to common gender norms. With that, we touch upon perhaps the most central aspect of from-maleto-female transsexuality, because given the narrow needle's eye, the person in question has no other choice than to make femininity appear as convincing as possible, which means living up to a stereotypical gender role (see Greer, 1999: 65). Borchgrevink (1987: 82) points out that various studies show that transsexuals' elaboration of themselves as social persons is more in accordance with what 'culture expects' of men and women, than what goes for people at large.

There is little doubt that the qualities that are - or have to be - emphasized define the women in a subordinate position. Transsexual men identify themselves as women by being passive, care oriented, emotional and 'intuitive' (Borchgrevink, 1987: 83). Also, occupational preferences 
appear to be unambiguous: secretary, waitress, hairdresser, showbusiness and so on. (And they seem to have a strong wish for earning less than men.) Acceptance of and adaptation to the gender-divided labour market is actually a condition for being recommended for surgery; it is considered as 'high motivation'. However, the most highly prioritized 'occupational preference' is that of housewife (married, being provided for, at home) (Borchgrevink, 1987: 84-5). The clinics even offer education in living as the opposite sex, where it is taught how to make up, how to dress properly, how to walk and sit properly, and correct intercourse positions (Borchgrevink, 1987: 87). In this way, bordering on caricature, transsexuals are prepared for reproducing the symbolic pattern of gender roles.

Borchgrevink's material reveals that for the sex operated, freedom of choice and liberation goes hand in hand with submission and confinement. Like the Muslim and the anorexic, the transsexual makes a choice that contributes to marking the hierarchical inequality between masculinity and femininity. Just as explicitly as the others, if not more, the transsexual demonstrates that femininity is complementary to masculinity, and that femininity implies submission. The 'fact' that women are doomed to live in immanence is confirmed, and that is not only because of the body, but most of all because of the spirit. The hierarchy is both the source and the result of transsexuality.

We may say that, as with the two other figures, the transsexual uses freedom of choice to choose submission. There is, however, a significant difference here, because in this case we can attach choice and control directly to masculinity (before the operation) and submission directly to femininity (after the operation). Hence, the connection between masculinity and transcendence and femininity and immanence becomes exceptionally clear. The transsexual demonstrates an extraordinary transcendence combined with an extraordinary immanence.

\section{THE MONSTROUS}

In each way, the Muslim wearing the veil, the female anorexic and the from-man-to-woman transsexual demonstrate a structural ambivalence of transcendence and immanence attached to the notion of woman, within a hierarchical order. And with that, the three figures make visible the hierarchy on which the modern, egalitarian understanding of society is based, and thereby strike the society where it is most vulnerable.

We may say that their demonstrative character makes the three figures monstrous, if we look at Latin meaning of the word. Monster/monstrum is primarily an object of display, according to Rosi Braidotti $(1994,1996)$. She points out that the monster de-monstrates God's will, and monstrum can be associated with moneo, which means to warn. Furthermore, the 
monster is always ambivalent in that it evokes both horror and fascination, and finally, the monster is associated with excess, lack and displacement in relation to something else, namely the normal human being. In that sense, the monster is in a liminal position, contributing to uphold the dominant view of subjectivity.

The monstrous can be seen as effects of, and constitutive of, certain discursive practices directed at re-establishing balance and recreating order by returning the monster figures to the fold. It happens by turning them into pathologies, which explains why the three figures, in respective ways, are turned into victims and thereby cut off from freedom of choice and control. In the first case it occurs through an 'us-them' discourse, where the veiled woman is ascribed the role as an Other in a cultural sense, while attention is diverted from the dominant cultural order. In the second case, it occurs through a 'healthy-sick' discourse, where the anorexic woman is given a diagnosis, while the surrounding society is given a clean bill of health. In the third case, we witness a 'normal-deviant' discourse, where the transsexual is constituted as deviant in a psychiatric sense, while the normality of the surrounding society is affirmed (see Sirnes, 1999; Solvang, 2000). But despite all attempts to control the abnormal, it will not disappear, insofar as it is constituted by, and constitutive of, normality. As Braidotti (1996: 150) makes clear, the monster is always going to get us.

\section{NOTES}

I would like to thank Henrik Kjærum for his careful work on the translation, and Cathrine Egeland, Yngve Lithman, Christine Jacobsen and the two referees for their valuable comments.

1. The debate about the Muslim veil (hijab) started in France in 1989, when three girls were expelled from a school in Creil outside Paris, after refusing to unveil. But the debate is not confined to France. It takes place in many countries, and it has a long history, as is elaborated in the text.

2. The gap is to be overcome by a civilizing process oriented towards universal subjectivity as the basis for an inclusive humanity. Thus modern ideologies, like the liberal and republican, are oriented towards a utopian goal that does not allow any autonomy (since the goal is indistinct or undifferentiated). This is only half the truth, however, because, as indicated, the ideal of universality does not require autonomy as such to be eliminated, as long as the autonomous citizen is the object of the civilizing process. Autonomy is both the starting point and the end; as starting point autonomy is uncivilized, as an end it is civilized (Gressgård, 2002). Only the civilized (male) autonomous subject can possess or display the attributes required of the equal human being, the mature citizen (see Arendt, 1973: 300-2; Dean, 1999: 134-5, 146), and as an ideal human being, he sets the standards for civilization. It is, in other words, the incorporation of the universal subject into the autonomous subject that makes it possible for a certain culture to represent 
humanity as a whole. Along these lines, Dumont (1996) notes that the German nation becomes the exemplary example of humanity, a perfect incorporation of a universal idea. His reference is the political philosopher Fichte, who adopts the current stereotypes of the excellence of the German character in order to state a hierarchy among peoples in the name of the very value of universalism (Dumont, 1996: 123). In Dumont's subsequent comparison of German and French ideology, he concludes that the Germans saw themselves as superior qua Germans, while the French consciously postulated only the superiority of the universalist culture, but identified with it so naively that they looked on themselves as the educators of mankind (Dumont, 1996: 131; see also Barthes, 1973).

3. It is particularly the Kantian philosophical tradition that is associated with 'secular' transcendence, where the human spiritual, intelligible world stands in contrast to the physical world's causal relations, and this opposition corresponds to the moral distinction between duty and inclination. Duty denotes freedom, and is achieved by controlling one's bodily impulses and preferences, with our actions being directed towards higher ideals and values. This is a modern, idealist concept of freedom. But the need for distancing oneself from the animal aspects of life can also be found in the philosophy of Plato, and later Augustin, where the life of the mind is prioritized over physical existence. This idea has influence the whole western way of thinking, including modern, existentialist thought, in which the human being is considered to have a desire to transcend features associated with nature. In de Beauvoir's (1952) philosophy, transcendence is linked to progression, and expresses (male) individual subjectivity. The male's vocation is to transcend towards the totality of the universe and the infinity of the future (Lyotard, 1992: 37). Immanence, on the other hand, is linked to maintenance and cyclical time, in the sense of sustaining life, and these (female) activities cannot express individuality (de Beauvoir, 1952). In Sartre's thought human beings have the ability to transcend physical placing; they have the freedom to shape their lives and thoughts (Clack, 2002: 6). This concept of freedom of choice is reflected in later sociology of reflexivity (i.e. Giddens, Beck). Classical liberalism (i.e. Hobbes, Locke, Hume) can also be seen as directed towards transcendence, in the sense of liberation from hindrances or constraints. To the extent that man is prevented from doing that he has a will to do, he is not free. This 'negative' concept of freedom is constitutive of most democratic political models in the West.

4. Christian asceticism is often understood as if relinquishing oneself implies relinquishing the body for the benefit of the spirit. This, according to Halvor Moxnes (2002), is a misunderstanding. The problem is not the body as such; asceticism is primarily directed against desire: 'It is desire that drives men to sexual activities that create bodily unions with prostitutes (1 Corinthians, 6 ), and thus connect them to the godless world. The alternative is not a disembodied existence, but to become "one with Christ in body"' (Moxnes, 2002: 64). Furthermore Moxnes argues that the sign of the bodily union with Christ is the Spirit thence becoming a bodily phenomenon: 'The spirit lives in man (Rom. 8.9-11; Corinthians 6.19) .. . This Paul contrasts to sin, "flesh", "evil nature", or "desire" (Rom. 8.12; Gal. 5.16-18), and these parties, so to speak, are in conflict forming the bodily and social life of mankind' (Moxnes, 2002: 65). I return to the relation between the human body and Christ later in the article, where the theme of female anorexics is discussed. 
5. For instance, Susan M. Okin (1999) points to a series of cultural practices and ideologies connected to gender that is directed towards controlling women and making them into slaves for men's interest and desires (here among, wearing the veil). Women who endorse such practices are presented as victims of some kind of false consciousness, not knowing their own good. Okin does not, however, base her argument on Marx's expressive materialist concept of freedom, in contrast to alienation, nor does she relate to the existentialist concept of freedom of choice, in contrast to bad faith. Her argument is predominantly liberal, directed against constrained choices.

6. A main argument against the veil is that it suppresses women by being an expression of a patriarchal culture, in contrast to the egalitarian culture of the West. In many cases, the debates seem to be informed by the idea of the clash of civilizations (Huntington).

7. This is, of course, only one way of understanding the Muslim veil. Nevertheless, it represents a widespread opinion among Muslims living in western societies (Roald, 2001).

8. Also, Muslim traditions provide the man with a prior right to transcendence of materialism towards eternity or divinity. As is the case with Christianity, the woman within most Islamic traditions is looked upon as incomplete in comparison to the man. An exception is found within Islamic mysticism, Sufism, where women may manifest the divine, although in some cases they are characterized as men encased in female bodies. It is just as likely, however, that due to her sex, the woman may personify evil (Schimmel, 1997). A parallel is found in the mediaeval mysticism of Christianity. This I return to, when looking at female anorexics.

9. See also among others Bell (1985), Bell and Mazzoni (2003), Mazzoni (1996) and Vandereycken and van Deth (1994).

\section{REFERENCES}

Agamben, G. (1998) Homo Sacer: Sovereign Power and Bare Life. Stanford, CA: Stanford University Press.

Ahmed, L. (1992) Women and Gender in Islam: Historical Roots of Modern Debate. New Haven, CT and London: Yale University Press.

Arendt, H. (1973) The Origins of Totalitarianism. New York: Harvest Book.

Barthes, R. (1973) Mythologies. London: Paladin.

Bell, R.M. (1985) Holy Anorexia. Chicago, IL: Chicago University Press.

Bell, R.M. and C. Mazzoni (2003) The Voices of Gemma Galgani: The Life and Afterlife of a Modern Saint. Chicago, IL: Chicago University Press.

Borchgrevink, T. (1987) Kjærlighetens Diktatur. Kjønn, arbeidsdeling og modernitet [The Dictatorship of Love: Sex, Division of Labour and Modernity], Occasional Papers in Social Anthropology No. 21. Oslo: University of Oslo.

Braidotti, R. (1991) Patterns of Dissonance. Cambridge: Polity Press.

Braidotti, R. (1994) Nomadic Subjects: Embodiment and Sexual Difference in Contemporary Feminist Theory. New York: Columbia University Press.

Braidotti, R. (1996) 'Signs of Wonder and Traces of Doubt: On Teratology and Embodied Differences', pp. 135-52 in N. Lykke and R. Braidotti (eds) Between Monsters, Goddesses and Cyborgs: Feminist Confrontations with Science, Medicine and Cyberspace. London and New York: Zed Books.

Butler, J. (1990) Gender Trouble. New York and London: Routledge. 
Bynum, C.W. (1987) Holy Feast and Holy Fast: The Religious Significance of Food for Medieval Women. Berkeley: University of California Press.

Clack, B. (2002) Sex and Death: A Reappraisal of Human Mortality. Cambridge: Polity Press.

Dean, M. (1999) Governmentality: Power and Rule in Modern Society. London, Thousand Oaks, CA and New Delhi: Sage.

De Beauvoir, S. (1952) The Second Sex. New York: Random House.

Donald, J. (1996) 'The Citizen and the Man About Town', pp. 170-90 in S. Hall and P. du Gay (eds) Questions of Cultural Identity. London, Thousand Oaks, CA and New Delhi: Sage.

Dumont, L. (1970) Homo Hierachicus: The Caste System and Its Implications. Chicago, IL: University of Chicago Press.

Dumont, L. (1996) Essays on Individualism: Modern Ideology in Anthropological Perspective. Chicago, IL: University of Chicago Press.

Greer, G. (1999) The Whole Woman. London: Doubleday.

Gressgård, R. (2002) ‘Dilemmaet mellom likeverdighet og særegenhet som ramme for flerkulturell dialog' [The Dilemma between Equal Dignity and Specificity as Structural Framework for Multicultural Dialogue], Dr.polit. thesis. University of Bergen.

Gressgård, Randi and Christine Jacobsen (2003) 'Questions of Gender in a Multicultural Society', Nordic Journal of Women's Studies (NORA) 11(2): 69-77.

Grosz, E. (1994) Volatile Bodies. Bloomington: Indiana University Press.

Haavind, H. (1982) 'Makt og kjærlighet i ekteskapet' [Power and Love in Marriage], pp. 138-71 in R. Haukaa, M. Hoel and H. Haavind (eds) Kvinneforskning: Bidrag til samfunnsteori [Gender Research: Contributions to Social Theory]. Oslo: Universitetsforlaget.

Irigaray, L. (2004) Key Writings. London: Continuum.

Jacobsen, C. (2002) Tilhørighetens mange former. Unge Muslimer i Norge [The Many Forms of Belonging: Young Muslims in Norway]. Oslo: UniPax.

Linke, U. (1999) Blood and Nation: The European Aesthetics of Race. Philadelphia: University of Pennsylvania Press.

Lloyd, G. (1984) The Man of Reason: 'Male' and 'Female' in Western Philosophy. London: Methuen.

Lyotard, J.-F. (1992) The Postmodern Explained to Children. London: Turnaround.

Mazzoni, C. (1996) Saint Hysteria: Neurosis, Mysticism, and Gender in European Culture. Ithaca, NY: Cornell University Press.

Mosse, G.L. (1985) Nationalism and Sexuality: Middle-Class Morality and Sexual Norms in Modern Europe. Madison: The University of Wisconsin Press.

Moxnes, H. (2002) 'Mannens begjær som moralsk problem. Foucault og Paulus om formingen av subjektet i antikken' [Male Desire as a Moral Problem: Foucault and Paul on the Formation of the Ancient Subject], pp. 25-72 in H. Moxnes, J. Børtnes and D.E. Ensjø (eds) Naturlig sex? Seksualitet og kjønn i den kristne antikken [Natural Sex? Sexuality and Gender in the Christian Antiquity]. Oslo: Gyldendal Akademisk.

Norman, K. (1991) A Sound Family Makes a Sound State: Ideology and Upbringing in a German Village, Studies in Social Anthropology No. 24. Stockholm: University of Stockholm.

Okin, S.M. (1999) 'Is Multiculturalism Bad for Women?', pp. 7-26 in C. Joshua and H. Matthew (eds) Is Multiculturalism Bad for Women? Princeton: Princeton University Press.

Økland, J. (2002) 'Intet nytt under Kristus. En dialog med Bernadette Brooten om kvinners "unaturlige" begjær i antikken' [Nothing New under Christ. A 
Dialogue with Bernadette Brooten on Women's 'Unnatural' Desires in Antiquity], pp. 129-73 in H. Moxnes, J. Børtnes and D.E. Endsjø (eds) Naturlig sex? Seksualitet og kjønn i den kristne antikken [Natural Sex? Sexuality and Gender in the Christian Antiquity]. Oslo: Gyldendal Akademisk.

Ortner, S.B. (1996) Making Gender: The Politics and Erotics of Culture. Boston, MA: Bacon Press.

Prieur, A. (2002) 'Magt over eget liv: om unge indvandrere, patriarkalske familieformer og nordiske ligestillingsidealer' [Control Over One's Own Life: About Young Immigrants, Partriarchical Family Forms and Nordic Ideals Of Gender Equality], pp. 149-67 in A. Borchorst (ed.) Kønsmagt under forandring [Shifting Power of Gender]. Copenhagen: Hans Reitzels Forlag.

Roald, A.S. (2001) Women in Islam: The Western Experience. New York and London: Routledge.

Schimmel, A. (1997) My Soul is a Woman: The Feminine in Islam. New York and London: Continuum.

Sirnes, T. (1999) “"Alt som er fast, fordamper?" Normalitet og identitet i endring' [All that is Solid Melts into Air: Transformation of Normality and Identity], pp. 29-75 in S. Meyer and T. Sirnes (eds) Normalitet og identitetsmakt i Norge [Normality and the Power of Identity in Norway]. Oslo: Ad Notam Gyldendal.

Skottestad, L.U. (2003) 'Balansekunst: En analyse av hvordan en gruppe kvinner og kirurger redegjør for valg av brystforstørrelse' [A Fine Balance: An Analysis of a How a Group of Women and Surgeons Account for the Choice of Breast Enlargement], master's thesis, University of Tromsø.

Solheim, J. (1998) Den åpne kroppen. Om kjønnssymbolikk i moderne kultur [The Open Body: Gender Symbolism in Modern Culture]. Oslo: Pax.

Solvang, P. (2000) 'The Emergence of an Us and Them Discourse in Disability Theory', Scandinavian Journal of Disability Research 2(1): 3-19.

Vandereycken, W. and R. van Deth (1994) From Fasting Saints to Anorexic Girls: The History of Self-Starvation. London: Athlone.

Wegling, M. (2002) Den guddommelige anoreksi [Divine Anorexia]. Oslo: Aschehoug.

Randi Gressgård is an associate professor in sociology at the University of Stavanger, Norway. She is also a researcher in the field of international migration and ethnic relations (IMER). Her doctoral thesis (2002) dealt with the multicultural dilemma between equal dignity and cultural specificity, and is now being prepared for international publication. Her recent research focuses on the intersection between nation, gender and sexuality. Address: Department of Media, Culture and Society, University of Stavanger, N-4036 Stavanger, Norway. [email: randi.gressgard@uis.no] 